\title{
16. PRELIMINARY CORRELATION OF QUATERNARY VOLCANIC ASHES FROM THE MIDDLE AMERICA TRENCH OFF GUATEMALA, DEEP SEA DRILLING PROJECT LEG 671
}

\author{
William I. Rose, Jr., Theodore J. Bornhorst, and John W. Drexler, Department of Geology and Geological \\ Engineering, Michigan Technological University, Houghton, Michigan
}

\begin{abstract}
Mineralogical identification, glass chemistry, and instrumental neutron activation analyses of Quaternary volcanic ash layers from Leg 67 Holes 496, 497, and 499 are used to correlate the drill holes and on-land sources. We have identified two units at Hole 496 that correspond to the 23,000-yr.-old Piños Altos ash (Samples 496-3-4, 55-57 cm and 496-3-5, 74-76 cm); the 84,000-yr.-old Los Chocoyos ash corresponds with Sample 496-5-4, 134-146 cm, but this latter correlation is less certain.
\end{abstract}

\section{INTRODUCTION}

Following the work of Bowles et al. (1973), a series of studies has established tephrochronological correlations among deep-sea ashes in the equatorial Pacific and with on-land sources (Hahn et al., 1979; Drexler et al., 1980; Peterson, 1980; and Rose et al., in press). The objective of this paper is to extend the correlations suggested in previous work to the DSDP Leg 67 cores taken adjacent to Guatemala. We also hope the correlations will provide a basis for characterizing early Quaternary volcanism in Guatemala.

\section{SAMPLING}

We sampled discrete and disseminated ashes where ash was recorded in the sedimentologic logs. Only Quaternary ashes were selected, because for correlation purposes there is little information available on older ash. Only rhyolitic (light-colored) ashes were studied, because these are the most widely disseminated layers. To date, even rhyolitic Quaternary ashes are incompletely sampled. Figure 1 shows the ashes we studied, the type of information gathered, and the correlations we have evidence for so far.

\section{SAMPLE PREPARATION AND ANALYSIS}

The samples were placed in a 50-ml evaporating dish and washed with distilled water until the majority of suspended particles were removed. Carbonate was removed by adding dilute $\mathrm{HCl}$ solution. Organic material was cleaned from the sample by treatment with warm hydrogen peroxide.

Glasses were mounted in epoxy and analyzed by a MAC 400 electron microprobe using a KEVEX Magic energy dispersive system. A beam current of $0.03 \mu \mathrm{A}$ and a beam diameter of about $10 \mu \mathrm{m}$ were used at an accelerating voltage of $15 \mathrm{kV}$. Yellow-stone rhyolitic glass USNM 72834 was used as a standard (Jarosewich et al., 1980).

Instrumental neutron activation analyses (INAA) were made at the Phoenix Memorial Laboratory of the University of Michigan, Ann Arbor, Michigan following the procedure of Drexler et al. (1980). Analytical errors are similar to those given by Rose et al. (1979) and Hahn et al. (1979).

We examined all ashes optically. Mineralogical species, proportions, and morphology of the glass were recorded.

\footnotetext{
${ }^{1}$ Aubouin, J., von Huene, R., et al., Init. Repts. DSDP, 67: Washington (U.S. Govt. Printing Office).
}

\section{GENERAL CHARACTERISTICS OF THE ASH}

All of the ashes are calc-alkalic and range from dacite to rhyolite. Mineralogically they contain vesicular glass, plagioclase, and one or more of the following mafic minerals: hornblende, pyroxene, or biotite. A few of the ash layers were mixed basalt-rhyolite or dacite-rhyolite units. All of these characteristics are typical of the onland ashes of Guatemala.

\section{CORRELATIONS}

We feel confident of two correlations (solid lines in Fig. 1) in this study. We believe that two layers in Hole 496 (Sample 496-3-4, 55-57 cm and 496-3-5, 74-76 cm) correlate with the Piños Altos ash of Ayarza caldera, Guatemala (Tables 1,2). This ash has also been tentatively correlated with another deep-sea layer found at $33 \mathrm{~cm}$ in core RC12-32 (Peterson, 1980). The Piños Altos ash has been dated as $23,000 \mathrm{yr}$. old by $\mathrm{C}^{14}$ determinations on logs within the associated ash-flow deposits near the caldera. We are also confident of an interhole correlation between Hole 496 (Sample 496-12-2, 54-56 cm) and Hole 497 (Sample 497-12-1, 20-22 cm) (Table 1). These ashes are identical in composition and mineralogy.

We suggest, on the basis of preliminary results, three other tentative correlations (dashed lines in Fig. 1): a thick ash layer at Sample 496-5-4, 134-146 cm is probably correlative with the Los Chocoyos ash of Hahn et al. (1979) (Table 2). Another ash sampled at Hole 497 (Sample $497-5-2,112-113 \mathrm{~cm}$ ) is probably also correlative with the Los Chocoyos unit. The Los Chocoyos ash has been correlated with the D layer in equatorial Pacific cores and with the Y8 layer in the Gulf of Mexico and Caribbean Sea; it has been dated as $84,000 \mathrm{yr}$. old (Drexler et al., 1980). Because the Los Chocoyos ash is the largest young rhyolitic unit known on land, it is not surprising that it correlates with the thickest ash in the Hole 496 core. The mineralogical data and glass compositions indicate a correlation, but INAA data now in progress will be the final check.

Trace element data by INAA suggest a correlation between ashes in Holes 499 (Sample 499-13-3, 148-150 


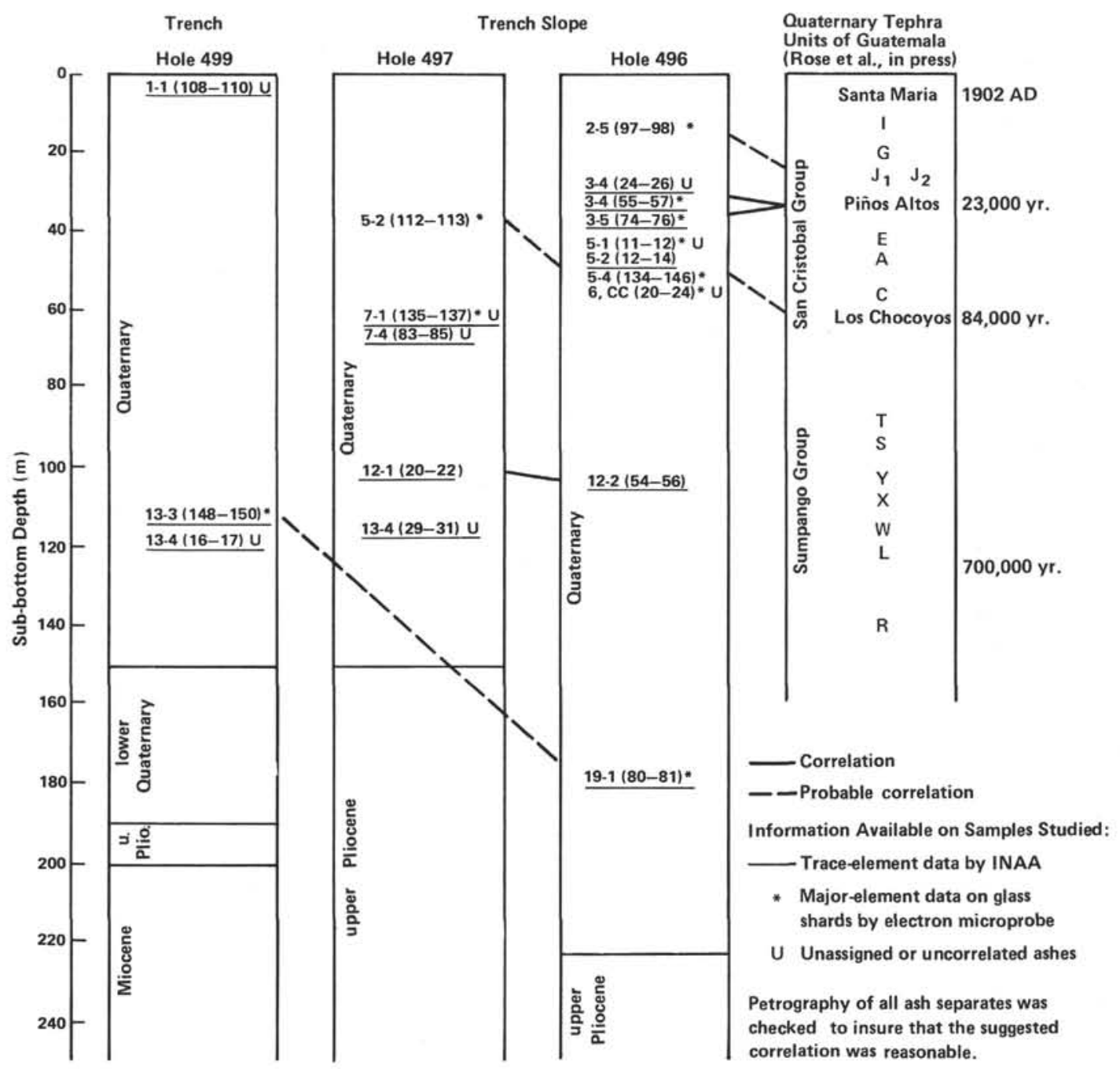

Figure 1. Stratigraphic column from Holes 496, 497, and 499, Leg 67, DSDP, Middle America Trench, Guatemala Transect. (Stage boundaries are from Sites 496, 497, and 499 reports, this volume. Numerals in the DSDP hole columns signify core-section [interval in $\mathrm{cm}$ ]; capital letters in the last column [Quaternary tephra units of Guatemala] signify tephra deposits of Guatemala from Rose et al., in press).

Table 1. Instrumental neutron activation analyses of selected ashes from DSDP Leg 67 (values listed in ppm).

\begin{tabular}{lccccc}
\hline & \multicolumn{5}{c}{ Samples (interval in cm) } \\
\cline { 2 - 6 } & $\begin{array}{c}497-12-1 \\
(20-22)\end{array}$ & $\begin{array}{c}496-12-2 \\
(54-56)\end{array}$ & $\begin{array}{c}496-3-4 \\
(55-57)\end{array}$ & $\begin{array}{c}496-3-5 \\
(74-76)\end{array}$ & $\begin{array}{c}\text { Piños Altos } \\
\text { Ash }^{\mathrm{a}}\end{array}$ \\
\hline $\mathrm{Ba}$ & 1710 & 1220 & 742 & 749 & 793 \\
$\mathrm{Ce}$ & 31.1 & 32.1 & 52.2 & 30.1 & 51.4 \\
$\mathrm{Co}$ & 2.7 & 1.6 & 0.6 & 2.2 & 0.7 \\
$\mathrm{Cs}$ & 2.2 & 2.0 & 3.5 & 3.1 & 3.1 \\
$\mathrm{Eu}$ & 0.95 & 0.91 & 0.77 & 0.74 & 0.82 \\
$\mathrm{Hf}$ & 4.0 & 4.5 & 4.0 & 4.2 & 4.3 \\
$\mathrm{La}$ & 14.5 & 14.4 & 22.4 & 23.0 & 24.4 \\
$\mathrm{Lu}$ & 0.44 & 0.41 & 0.42 & 0.42 & 0.5 \\
$\mathrm{Nd}$ & 14.3 & 11.0 & 16.0 & 14.7 & 19.6 \\
$\mathrm{Rb}$ & 77 & 78 & 142 & 86 & 119 \\
$\mathrm{Sc}$ & 6.7 & 5.3 & 3.1 & 5.6 & 2.6 \\
$\mathrm{Sm}$ & 3.4 & 3.4 & 3.8 & 3.8 & 3.5 \\
$\mathrm{~Tb}$ & 0.68 & 0.59 & 0.54 & 0.62 & 0.69 \\
$\mathrm{Th}$ & 7.6 & 7.8 & 18.1 & 18.8 & 9.4 \\
$\mathrm{U}$ & 2.0 & 2.0 & 3.7 & 3.4 & 3.3 \\
$\mathrm{Yb}$ & 3.0 & 2.8 & 3.7 & 2.7 & 2.0 \\
\hline $\mathrm{a}$ & & & & &
\end{tabular}

a Peterson, 1980.
Table 2. Composition of glasses in ashes from DSDP Leg 67 with ash layers from other studies (analyses by electron microprobe, listed as wt.\%).

\begin{tabular}{|c|c|c|c|c|c|c|}
\hline $\begin{array}{c}\text { Sample } \\
\text { (interval in } \mathrm{cm} \text { ) }\end{array}$ & $\begin{array}{c}497-5 \cdot 2 \\
(112-113)\end{array}$ & $\begin{array}{c}\begin{array}{c}496-5-4 \\
(134-146)\end{array}\end{array}$ & $\begin{array}{l}\text { Los Chocoyos Ash } \\
\text { 'D' Layer }\end{array}$ & $\begin{array}{l}496-3-4 \\
(55-57)\end{array}$ & $\begin{array}{l}496-3-5 \\
(74-76)\end{array}$ & $\begin{array}{l}\text { Piños Altos } \\
\text { Asth }\end{array}$ \\
\hline $\mathrm{SiO}_{2}$ & 73.2 & 72.0 & $71.5-74.7$ & 72.1 & 72.6 & 71.3 \\
\hline $\mathrm{Al}_{2} \mathrm{O}_{3}$ & 12,3 & 12.6 & $11.8-12.4$ & 12.8 & 12.9 & 12.3 \\
\hline $\mathrm{FeO}^{\circ}$ & 0.6 & 0.8 & $0.38-0.52$ & 0.75 & 0.75 & 0.9 \\
\hline $\mathrm{Na}_{2} \mathrm{O}$ & 2.4 & 3.9 & $3.23-4.24$ & 3.1 & 2.2 & (1.6) \\
\hline $\mathrm{K}_{2} \mathrm{O}$ & 4.3 & 3.7 & $3.30-3.99$ & 3.8 & 3.7 & 3.7 \\
\hline $\begin{array}{l}\text { No. } \\
\text { Analyses }\end{array}$ & 4 & 4 & 50 & 5 & 5 & 14 \\
\hline
\end{tabular}

$\mathrm{cm})$ and 496 (Sample 496-19-1, 80-81 cm). This correlation is marginal (coefficient of similarity $=0.79$ ), but it is supported by glass chemistry. We are hesitant about an unequivocable correlation, however, because the Hole 496 ash is much poorer in mafic minerals.

Finally, the youngest ash we examined in Hole 496 (Sample 496-2-5, 97-98 cm) is tentatively correlated with the J-tephra on land in Guatemala. This unit represents 
the youngest tephra of the Amatitlán caldera (Rose et al., in press). It has not been specifically dated but is younger than the 23,000-yr.-old Piños Altos unit.

We expect to take advantage of these initial correlations to study early Quaternary volcanism, which is recorded lower in the DSDP cores. Because of tropical plant growth, the evidence for such units and their sources is easier to obtain from deep-sea cores than from subaerial exploration.

There are several ash layers that we were unable to correlate with either on-land sources or with ashes in another core. These are also labeled in Figure 1.

\section{ACKNOWLEDGMENTS}

This work was supported by the National Science Foundation through Grant No. EAR-7920076. The cooperation and help of the Phoenix Memorial Laboratory, Ann Arbor, Michigan and J. Jones and W. Rigot are appreciated.

\section{REFERENCES}

Bowles, F. A., Jack, R. N., and Carmichael, I. S. E., 1973. Investigations of deep sea volcanic ash layers from equatorial Pacific cores. Geol. Soc. Am. Bull., 84:2371-2388.
Drexler, J. W., Rose, W. I., Jr., Sparks, R. S. J., and Ledbetter, M. T., 1980. The Los Chocoyos Ash, Guatemala: a major stratigraphic marker in middle America and in three ocean basins. Quat. Res., 13:327-345.

Hahn, G. A., Rose, W. I., Jr., and Meyers, T., 1979. Geochemical correlation of genetically related rhyolitic ash-flow and air-fall ashes, central and western Guatemala and the equatorial Pacific. Geol. Soc. Am. Spec. Pap., 180:101-112.

Jarosewich, E., Nelen, J. A., and Norberg, J. A., 1980. Reference samples for electron microprobe analysis. Geostandards Newsletter, 4(1):43-47.

Peterson, P. S., 1980. Tephra of the Laguna De Ayarza calderas of southeastern Guatemala and its correlation to units of the Guatemalan highlands [M.S. dissert.]. Michigan Technological University, Houghton, Mi.

Rose, W. I., Jr., Grant, N. K., and Easter, J., 1979. Geochemistry of the Los Chocoyos Ash, Quezaltenango Valley, Guatemala. Geol. Soc. Am. Spec. Pap., 180:87-99.

Rose, W. I., Jr., Hahn, G. A., Drexler, J. W., Malinconico, M. L., Peterson, P. S., and Wunderman, R. L., in press. Quaternary tephra of northern Central America. In NATO, Adv. Study Inst., Iceland, Self, S., and Sparks, R. S. J. (Eds.), Tephra Studies as an Aid in Quaternary Research: Holland (Reidal Publ. Co.). 